\title{
13a Swearing oaths in the authorial person
}

\author{
I.C. Torrance
}

The authorial voice makes an appearance in many Greek literary genres, but the number of authors who swear in the authorial person is remarkably low. Major archaic and classical authors such as Homer, Hesiod, Herodotus, and Thucydides never use a first-person oath in the authorial voice, a fact that is particularly striking in the cases of Hesiod (who spends much of his time, especially in Works and Days, speaking in his own name in a quite specific persona), and of Herodotus (who regularly gives his own opinion on reported events). In several cases the extant works of an author contain just one example of an oath sworn in the authorial person (Sappho, the anonymous Theognidea, Antisthenes, Aristotle, [Plato]). Among the poets Pindar is the author who most commonly uses the first-person oath and Bacchylides also (twice) uses the authorial oath in his epinicians. Aristophanes twice gives an oath in his own name, both times on the same issue but in two different plays. In prose texts, the works of Aeschines and Demosthenes contain by far the most first-person oaths, but other orators do not use them at all. Finally, Xenophon appears to use the authorial oath abundantly. However, all but two of the first-person oaths in his writings are spoken by Xenophon the character, and all but one of those appear in the Anabasis, which Xenophon famously ascribes in his Hellenica (3.1.2) to the otherwise unknown Themistogenes of Syracuse. In contrast to other works in which authorial oaths appear, there is a significant distance created in the Anabasis between Xenophon as author and Xenophon the character within the work. Memorabilia includes one oath by Xenophon as a character, and Hellenica and the Constitution of the Spartans each contain one oath in the authorial voice.

Since we have already discussed oaths in oratory, we can begin by reviewing the relevant findings regarding first-person oaths in this genre before moving on to other authors. Most of our discussion will be focused on Pindar and on Xenophon, but we will also discuss the other writers in whose works we find one or two authorial oaths before making some concluding remarks and returning to the question of why some authors use first-person oaths in their authorial voice and others do not.

\section{3a.1 The orators}

We saw in ch. 9 how Aeschines and Demosthenes exploited oaths for a variety of rhetorical purposes. Their speeches include numerous first-person informal 
oaths, and although it is beyond the scope of the present study to analyse all of these, we can summarize here the uses to which they were put. ${ }^{1}$ In Demosthenes, the oath of the imaginary objector "by Zeus" developed to become "little more than a sentence-adverbial" as an oath sworn in the author's own voice (e.g. Dem. 8.7). Similarly the oath "by Zeus" came to be used as a more emphatic version of the particle men "on the one hand", in both Aeschines and Demosthenes, drawing attention to the fact that although the statement made on oath is true, a more important one is about to be made (e.g. Aesch. 3.172, Dem. 6.23). When Aeschines and Demosthenes sought to add credibility to weak assertions, they tended to swear oaths not "by Zeus" but "by the gods", by more than one god, or by a god whose patronage was stressed by means of an epithet ${ }^{2}$ (e.g. Aesch. 1.55, Dem. 18.111, cf. Dem. 8.49).

First-person oaths are also found, though less frequently, in speeches composed for personal delivery by Demosthenes' and Aeschines' contemporaries - Apollodorus, Lycurgus and Hypereides ${ }^{3}$. There are none in Isocrates (who probably avoided them on principle - see ch. 15) or in the older orators such as Andocides and Lysias ${ }^{4}$.

\section{3a.2 Pindar and other poets}

Given that the authorial "I" features most prominently in lyric poetry amongst the poetic genres, it is not surprising to find that oaths sworn in the authorial person belong almost exclusively to this genre, with two additional examples from Old Comedy. The bulk of our relevant passages come specifically from epinician poetry, mostly from Pindar, ${ }^{5}$ but also from Bacchylides. The question of identifying the authorial "I" in epinician poetry is a vexed one. Does the "I" reflect the poet's own personal voice, and if so how can we reconcile this with a context of public and choral performance? Mary Lefkowitz argued that the persona loquens

1 On the frequencies of informal oaths in oratory, see §13.1. Martin 2009, 250-65 discusses the use of oaths in Demosthenes' private speeches. First-person informal oaths occur at Aesch. 1.28, 52, 55, 61, 69, 73, 76, 81, 88, 98, 108; 2.130; 3.172, 182, 212, 217, 228, 255; Dem. 1.19, 23; 3.32; 4.49; 6.23, 31; 8.7, 19, 28, 49; 9.54, 65, 70; 10.7, 17, 20, 25, 50; 13.16, 21; 14.38; 15.13; 16.13, 32; 18.13, 111, 129 , 208, 251, 261, 294, 307; 19.24, 46, 52, 67, 122, 129-30, 141, 171-2, 188, 212, 215, 235, 262, 285; 20.21, 151; 21.2, 3, 58, 109, 139, 198, 205, 207; 29.52, 57, 59; Prooem. 35.4, 35.5, 45.1, 46.3, 48.2.

2 On using epithets or invoking multiple divinities to add sanctity to oaths, see $\S 6.1$.

3 Apollodorus: [Dem.] 50.13; 52.9, 14. Lycurgus: Leocr. 76, 140. Hypereides: Eux. 4, 27; Dem. fr. 1.1.

4 Compare the pattern we found in ch.9 for the distribution of "imaginary objector" oaths.

5 Translations for Pindar given in this discussion are either taken from or based on Race 1997. 
in Pindar was the poet and that epinicians were essentially solo performances sung by "the poet or his delegate". ${ }^{6}$ This explains, according to Lefkowitz, why the "I" in the victory odes "always refers to the poet". ${ }^{7}$ This position was followed by Heath and was later defended by both Heath and Lefkowitz, ${ }^{8}$ after their arguments were challenged by several scholars. ${ }^{9}$ The poetic "I" in the epinicia has been understood in various other ways. D'Alessio emphasized the conflation of the poet's literary and social personae in first-person utterances. ${ }^{10}$ Goldhill stressed that the authorial "I" could equally well refer to the chorus collectively and speaks of a "generalizing ego". ${ }^{11}$ Bremer raised the notion of a "paradoxical ego" similarly aligning himself with the choralists, ${ }^{12}$ and Calame has recently coined the notion of a "polyphonic melic ego". ${ }^{13}$

The issue of poetic voice in Greek lyric poetry is complex and may never be entirely resolved. Perhaps the most persuasive explanations of Pindar's controversial authorial "I" come from scholars who stress both its personal and its choral potential. ${ }^{14}$ What is clear, however, about first-person oaths in epinician poetry is that they have an immediately obvious purpose in increasing the intensity of praise for the honorand, ${ }^{15}$ not just by making statements concerning their achievements but by making them on oath. In the context of praise, Richard Rawles' formulation of "an ambiguity of voice” in first-person declarations where there is "both the general acclaim of the community and the privileged voice of the poet" is persuasive. ${ }^{16}$ Hutchinson comments that the swearing of oaths is

6 Lefkowitz 1991, 1-71 (originally published in 1963), and 191-201 (original published in 1988) with 203-6, quotation from 203.

7 Lefkowitz 1991, 204.

8 Heath 1988, Heath and Lefkowitz 1991, Lefkowitz 1995 (responding primarily to D’Alessio 1994).

9 Especially Burnett 1989, Carey 1989 and 1991.

10 D’Alessio 1994.

11 Goldhill 1991, 144-5.

12 Bremer 1990. Other significant proponents of the chorus theory are Carey 1991 and Morgan 1993.

13 Calame 2011, esp. 137-8, whose focus is Bacchylides. As observed by Carey 1999, 18-19, Bacchylides generally prefers the third person to designate the poet (in contrast to Pindar); cf. Carey 1995b, 92-3, on the unusual prominence of the poetic persona in Pindar, and see also Fearn 2007, 40-1 on first person statements in Bacchylides.

14 E.g. Morgan 1993, 15 who argues that Pindar "submerges the choral into a virtually monodic personality". It is possible also that the odes were performed first by a chorus and that later reperformances were solos. On the issue of reperformances, see Currie 2004 and Morrison 2012. 15 On the centrality of praise to the poetics of Pindar, see Goldhill 1991, 128-66 with further references.

16 Rawles 2011, 147. 
"a conventional device" in the epinician genre, "commonly introduced with an unneeded vehemence and an elaborate emphasis on the ritual", and that "these endow the present with a degree of fiction". ${ }^{17}$ Hutchinson is right to stress the frequency of oaths of this type in the genre, ${ }^{18}$ but it is unclear why he finds the vehemence "unneeded" and even less clear why the oaths should "endow the present with a degree of fiction". In fact it seems to be the case that oaths function to stress the truth of the poet's claims, as I argue below. Moreover, within the seemingly basic function of high praise, there is a remarkably wide variety of expression, and the language of oaths fits comfortably into the broader framework of religious language and imagery used by Pindar and Bacchylides. ${ }^{19}$

In Pindar's Olympian 2 (for Theron of Acragas, winner of the chariot race in $476 \mathrm{BC})$, the poet casts himself as an archer shooting arrows of fame (2.82-91), and as "the divine bird of Zeus" (2.88). He continues: "Yes, bending the bow

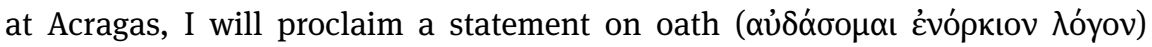
with a truthful mind ( $\dot{\alpha} \lambda \alpha \theta \varepsilon \tilde{c}$ vó $\omega)$, that no city within a century has produced a man more beneficent to his friends in spirit and more generous of hand than Theron" (2.92-5). Less than thirty lines beforehand (Ol. 2.65-7), the poet had made a general reference to the benefits reaped by good men who keep their oaths. These keep "company with the honoured gods" and "spend a tearless existence, whereas the others endure pain too terrible to behold". Pindar stresses a divine reward for keeping one's oath in addition to a divine punishment for breaking one. The specification of a particular divine reward for oath-keepers is unusual, since it is the conditional curse that is the essential component of an oath rather than a conditional blessing, and blessings, when they are mentioned, are normally referred to in vague terms. ${ }^{20}$ Certainly keeping company among the gods does not appear elsewhere in our sources as a perceived consequence for being true to one's oath. Bowra discusses this passage as an example of Pindar accepting unusual doctrines concerning the afterlife, ${ }^{21}$ and suggests that Pindar may

17 Hutchinson 2001, 384.

18 Cf. Burnett 1985, 57, Maehler 2004 ad Bacch. 5.42, and McDevitt 2009, 150 on Bacch. 8.19-21 where the oath is one of the elements listed as "the most common recurrent motifs of the epinician”. Maehler 1982 (I.ii), 100 finds the use of oaths in epinicians to make a strong affirmation "a little ostentatious".

19 On religious language and imagery in Pindar see Bowra 1964, 42-98. Goldhill 1991, 133-4 discusses the importance of charis for the interrelations between gods and men in Pindar. On the centrality of hero cult in Pindar, see Currie 2005. Carey 1999 discusses how the pathos created in the odes of Bacchylides emphasizes "the importance of piety" (28-9), among other issues.

20 See further below p. 359 with n. 63 on rewards for keeping one's oath.

21 Bowra 1964, 90; on the complex views of death expressed in Pindar see also Currie 2005, 
simply be proposing the reverse of perjurers being punished in Tartarus, as is implied in Homer. ${ }^{22}$ Nevertheless, it seems important to link this assessment to the subsequent oath made in the authorial persona. By swearing a true oath, Pindar implicitly places himself among the gods, possibly as a theios ane $\bar{r},{ }^{23}$ and consolidates the image of himself as the bird of Zeus against whom the crows (possibly Simonides and Bacchylides) cry vainly. ${ }^{24}$

Pindar is emphatic in asserting his own authority as a poet of innate wisdom, and as a prophet and interpreter of the Muses. ${ }^{25}$ The poet is no longer a mere vessel through whom the Muse sings, as in Homer. ${ }^{26}$ Pindar sees himself as an essential intermediary figure crafting poetry from the divine knowledge he receives from the Muses. There is thus an important degree of separation between the information provided by the Muses and Pindar's finished poetic product. So in Olympian 6 (for Hagesias of Syracuse, winner of the mule race, 472 or 468 BC), the poet compares Hagesias to the Theban seer and warrior Amphiaraus, and

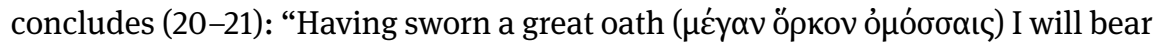
clear witness ( $\mu \alpha \rho \tau \nu \rho \eta ́ \sigma \omega)$ for him that this at least is so; and the honey-voiced

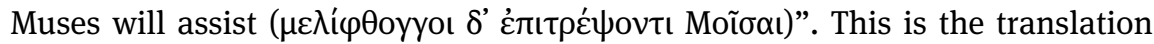
of Race, but Scodel translates the last phrase more literally "the honey-voiced Muses will permit me" and objects that several scholars do not translate within

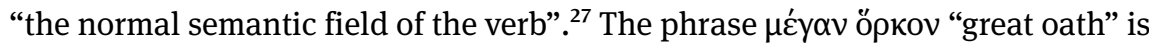
itself epic in diction, ${ }^{28}$ so that the contrast between epic and Pindaric expression seems to be underlined. In Pindar, the "honey-voiced Muses" produce "honey-

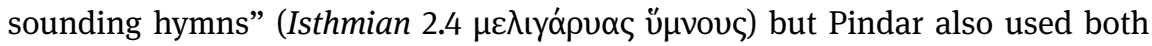
adjectives to describe his own poetry. In Isthmian 6 (for Phylacidas of Aegina, winner of the boys' pancration), the poem will be equivalent to "pouring a liba-

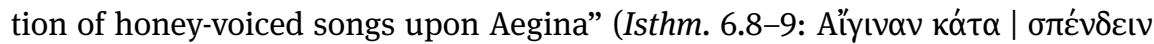

31-40.

22 Bowra 1964, 92.

23 The heroization or anticipated heroization of the living is significant in Pindar's work. Currie 2005, 158-200 discusses this issue within the broader context of fifth-century Greeks who arguably received religious treatment during their lifetime. D’Alessio 1994, 138 observes that Pindar "himself emphasized his relations with the gods and his religious piety."

24 On the identification of the crows as Simonides and Bacchylides, see Bowra 1964, 6-7, 10, 14, and cf. Race 1997, i, 73n.3, though Willcock 1995, 162-3 is not convinced by this identification. 25 See Bowra 1964, 1-41 esp. 3-8.

26 On the development of the poetic voice from Homer to Pindar, see Goldhill 1991, 69-166, and Scodel 2001.

27 Scodel 2001, 124 with n.31.

28 Cf. e.g. Il. 1.233, 9.132, 9.274, 19.113, Od. 2.377, 4.746, 5.178, 10.299, 10.343, 20.229. The expression is also used to describe the oath of the goddess Lachesis in Olymp. 7.64-8. 


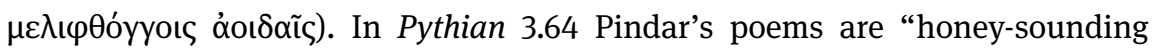

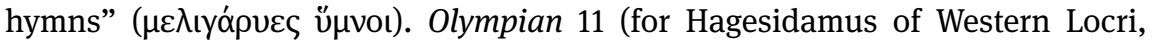
winner of the boys' boxing in 476 BC) opens with a priamel "in which the needs of sailors for winds and of farmers for rain are capped by the need of victors for commemorative songs": ${ }^{29}$ "if through toil someone should succeed, honey-sounding

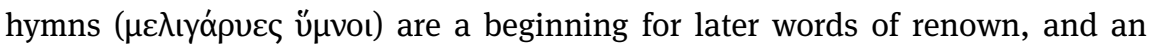
oath-pledge for great achievements ( 11.4-6). Here Pindar's "honey-sounding hymns" are a metaphorical oath, where the victory odes for Hagesidamus' first success are equivalent to a sworn pledge of future success. ${ }^{30}$ This use of oath-language is unusual and it emphasizes the authority and validity of Pindar's poetry. Goldhill reads this as "the divine access to truth provided by the Muses and justified by the oath", ${ }^{31}$ but Scodel observes that in his epinicia Pindar "never cites [the Muses] as an authority for his versions of a story, or for any other point of truth." Rather, "they render songs beautiful and appropriate." ${ }^{32}$ The distinction is important. The truth is, as Goldhill saw, justified by oaths, but it is the poet rather than the Muses who provides their content. It follows that, if Pindar's odes are tantamount to oath-pledges, then their content must be true.

The association of truth, oath, and sweet voice occurs in Olympian 13 (for Xenophon of Corinth, winner of the stadion and pentathlon, 464 BC). The poet proclaims “As for their victories (i.e. the victories of Xenophon's family) at the Isthmus and Nemea, in a brief word I shall reveal their sum, and my true witness

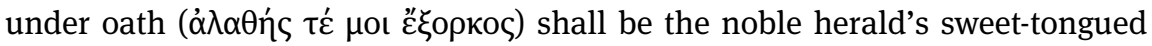
shout ( $\dot{\alpha} \delta$ ýy $\lambda \omega \sigma \sigma o \varsigma$ ßoó) heard full sixty times from both those places." (Olymp. 13.97-100). There is clearly a connection here once again between truth and oath. ${ }^{33}$ In this case listeners have just been told (with reference to Bellerophon capturing Pegasus) that the power of the gods can easily bring about what is “beyond oath" (Olymp. 13.83: $\pi \alpha \rho$ ' ö $\rho \kappa o v)$, or as Race translates "what one would swear impossible" (i.e. but would be wrong to do so), and what is "beyond expectation” (Olymp. 13.84: $\pi \alpha \rho \dot{\alpha} \dot{\varepsilon} \lambda \pi i \delta \alpha) .{ }^{34}$ In Olympian 13, Pindar cleverly uses the

29 Race 1997, i, 174.

30 Pindar uses the metaphor of an oath also in Nem. 9.16-17 where Eriphyle is given to Amphiaraus as wife "as an oath-pledge"; see ch. 3, p. 54.

31 Goldhill 1991, 150, having translated Olymp. 6.21 as "the sweet-voiced Muses will entrust me”, objected to by Scodel 2001, 124 n.31.

32 Scodel 2001, 123.

33 Cf. Pratt 1993, 118-19.

34 Certain other authors similarly warn against swearing that something is impossible, see $\S 5.2$ on Ajax (pp. 106-8) for further discussion. 
language of oaths in three ways. He emphasizes the near-impossibility of the successes achieved by the victor and his family, he asserts the truth of his claims, and his oath becomes the poetic "sweet-tongued shout", a metaphor for his poetry.

The oath in Nemean 7 (for Sogenes of Aegina, winner of the boys' pentathlon) is also connected to song. The passage reads as follows "One who knows me will proclaim if I come saying a crooked utterance out of tune. Sogenes from the clan of the Euxenidae, I swear ( $\dot{\alpha} \pi о \mu v \cup \dot{\omega} \omega)$ that I have not stepped up to the line and sent my tongue speeding like a bronze-cheeked javelin, which releases the strong neck from wrestling before the body falls under the blazing sun” (Nem. 7.68-73). Race, whose translation is quoted here, explains as follows: "The pentathlon could be won with enough victories in earlier events such as the javelin throw, thereby obviating the deciding wrestling match in the heat of the day. The implication is that Pindar will spare no effort in praising the victor." ${ }^{35}$ Carey observes that "Pindar's image of himself as a pentathlete implies a similar achievement on the part of the victor". ${ }^{36}$ The sentence preceding the oath implies that the oath is not a "crooked utterance out of tune", but is rather a melodious statement of truth. Lefkowitz comments on the fact that this phrase refers to poetry's potential, ${ }^{37}$ and it is striking that so many of the oaths spoken in Pindar's authorial persona are connected with an insistence on truth and on beautiful-sounding poetry. Of course it is well known that Pindar professed to create a poetry of truth in contrast to deceptive fictions. ${ }^{38}$ He consistently associates lying with blame and slander, and truth with his own poetry of praise. ${ }^{39}$ Since the oath is a tool for asserting unquestionable truths among the god-fearing in archaic and classical Greece, it is not surprising that Pindar exploits the language of oaths. Swearing oaths allows Pindar to stress the pious nature of his authorial voice, it enables him to emphasize the truth of his claims, and as such it can be associated with poetry itself, or at least with the kind of poetry that Pindar wishes to produce. It is significant that Pindar never refers to himself as a witness nor swears an oath

35 Race 1997, ii, 79 n.2. For a more detailed discussion of the meaning of this difficult passage see Burnett 2005, 197-8 (though Burnett treats the poetic "I" as the choral voice).

36 Carey 1981, 166.

37 Lefkowitz 1991, 140.

38 On the importance of truth for Pindar and his poetics, where the truth, alettheia, is intrinsically connected with memory through its etymological meaning as "un-forgetting", see e.g. Bowra 1964, 26-33, Nisetich 1980, 129, Hubbard 1985, 100-6, Pratt 1993, 115-29, Segal 1998, 105-32.

39 Archilochus is mentioned in negative terms as a poet of blame in Pyth. 2.54-6; cf. Most 1985, 186-7, Goldhill 1991, 141, Pratt 1993, 120, and the detailed discussion of the association of truth and praise in Pindar by Park 2013. 
when discussing mythological events, as observed by Most. ${ }^{40}$ Oaths are reserved for praise of the victor, ${ }^{41}$ since "in composing mythical narratives, even the truthful poet of praise fictionalizes."42

Most stresses the legal aspect of the language of oaths and witnessing, suggesting that Pindar is careful to avoid such expressions when referring to events of which he does not have a personal knowledge. ${ }^{43}$ However our final example of a Pindaric oath sworn in the authorial persona is one which serves to suggest the truth behind an ultimately unprovable claim, so that the connection between truth and authorial oaths seems to be of the utmost importance. In Nemean 11 (for Aristagoras of Tenedos on his installation as a councillor), Pindar suggests that the honorand had the potential to be victorious at wrestling in both Pythian and Olympian games if only his parents' extreme caution had not kept him away.

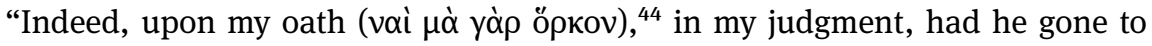
Castalia and to the well-wooded hill of Cronus, he would have had a more noble homecoming than his wrestling opponents" (Nem. 11.24-6). Pindar is careful to qualify his oath concerning a hypothetical outcome of events that did not occur

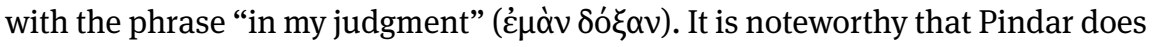
not do this when he makes sworn statements that are highly subjective in lavishing exaggerated praise on the ode's addressee. Who is to say, for example, whether or not Theron of Acragas really is the most generous man any city has produced for one hundred years (Olymp. 2.92-5), or whether Hagesias of Syracuse can reasonably be compared with the mythical Amphiaraus (Olymp . 6.15-21)? Pindar's use of the authorial persona's oath in these cases enables him to present opinion as fact. Elsewhere, as we have seen, Pindar swears oaths emphasizing the truth of his praise for the athletic victories of his honorands, and it seems he has imported the technique into Nemean 11 and adapted it to suit an ode which was not written to commemorate an athlete.

Like Pindar, Bacchylides uses oaths in the authorial voice to stress the truth of his praises since he too seeks to present poetic truth. ${ }^{45}$ Interestingly, Bacchylides

40 Most 1985, 176-7.

41 Pratt 1993, 122-3.

42 Pratt 1993, 125; see also Bundy 1986 [1962] 3-4, and Gerber 1982, 69-70 on Pindar's language of truth and falsehood as a rhetorical device. Carey 1995b, 99-103 discusses the fiction of spontaneity in the composition of Pindar's odes.

43 Most 1985, 176-7.

44 The expression is ambiguous, meaning either "I assert by my oath" or "By Horkos”. The latter would be an unusual invocation of the personification of Oath as a god, but it would suit Pindar's compressed poetic style. For further discussion of the god Horkos, see §12.1.

45 Carey 1999, 19, notes that the use of the oath for creating authority is one device shared by 
has a completely unique way of expressing his authorial oath, which eschews oath-language but makes reference to "resting a hand on the earth" (8.19: yõ $\delta$ '

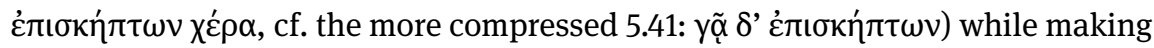
a statement. The action, as noted by LSJ (s.v. غ่лıкń $\pi \tau \omega$ II.3), is tantamount to calling the Earth (as goddess) to witness the statement. ${ }^{46}$ Only two examples survive. In one passage Bacchylides declares ( $\pi \iota \varphi \alpha u ́ \sigma \kappa \omega)$ that the dust of faster horses had never yet besmirched the horse of Hieron of Syracuse (as singlehorse victor at Olympia in $476 \mathrm{BC}$ ) in a contest as it rushed towards the finish line (5.41-5). ${ }^{47}$ The ode was composed to commemorate the same occasion as Pindar's first Olympian, which does not contain a first-person oath. ${ }^{48}$ It is possible that Bacchylides composed this victory ode with Pindar competitively in mind. Bowra discusses Bacchylides' unusually rich use of bird imagery here where lesser birds shrink from the metaphorical eagle of song, an uncannily similar pattern to that used by Pindar in Olympian 2, where (as we saw above) it is speculated that Bacchylides may have been designated as a crow. ${ }^{49}$ If he was indeed attempting to rival Pindar, it is interesting that he includes a first-person oath to stress the truth of his praise. In Bacchylides' only other first-person oath he will make his boast

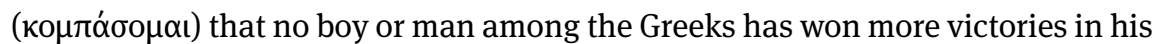
age group (8.19-21). ${ }^{50}$ The statement includes the parenthesis "every debt shines

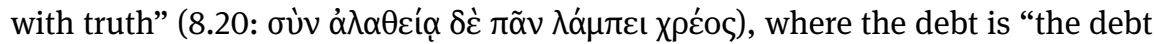
of praise owed by the poet to the victor", and the oath contributes to "an especially emphatic praise of the victor". ${ }^{51}$ Moreover, as Calame notes, "the poetic

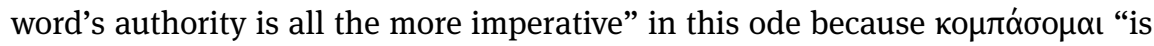
the 'performative future' and thus corresponds to the act of singing." 52 This use of the future gives the illusion of spontaneity to the performance, and is a technique

Pindar and Bacchylides. Pratt 1993, 116 observes that "Bacchylides' interest in poetic truth is expressed more directly than Pindar's, and he has virtually nothing to say about poetic lying or deception in his surviving verse." See also Burnett 1985, 58-9 on the association of truth and praise in Bacchylides.

46 See $§ 6.3$ on gestures in oath-taking.

47 Presumably, this means that the horse has won every race in which it has run.

48 Both odes seem to have been commissioned by Hieron, see Schmidt 1987.

49 Bowra 1964, 10-11. Other models also suggest themselves. Maehler 2004, 113 notes that the eagle scene is reminiscent of the flight of Persephone's chariot in the Homeric Hymn to Demeter. It seems clear, however, that the eagle in both Olymp. 2 and Bacch. 5 represents the poet. For further discussion, see Cairns 2010, 219-20.

50 The ode was probably written for Liparion of Ceos; see McDevitt 2009, 148-9.

51 McDevitt 2009, 150.

52 Calame 2011, 123. 
employed by Pindar and by other lyric poets, ${ }^{53}$ and we have seen that Pindar also uses the performative future with an oath in Olympian 2 when he states "I will

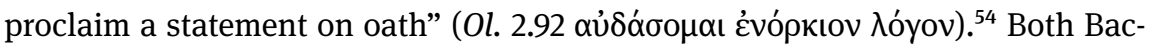
chylidean oaths are comparable to Pindaric sworn statements in their effusive praise of the addressee, but the notion of placing a hand on the earth raises an important question regarding performance. Did the performer(s) actually place a hand on the earth while reciting the passage? This would have made a striking dance move, and while the question cannot be answered with any certainty, it is worth noting that without the hand gesture there would technically be no oath, since the gesture itself is what constitutes calling the Earth to witness, turning the statement into an oath. If Bacchylides' use of the first person oath was in any way meant to rival Pindar's, then it stands to reason that the gesture was made in order to guarantee the oath's validity.

Elsewhere in lyric poetry oaths in the authorial voice are rare. Only the works of Sappho and the anonymous Theognidea contain one example each of an (informal) oath sworn in the authorial persona. The relevant passage from Sappho is a fragment (fr. 95.9-10) in which the poet states that she no longer gets any pleasure

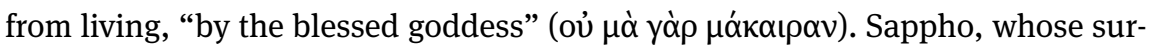
viving poetry is mostly love poetry of an often intimate nature, never (so far as we can tell) declares her love or desire for an addressee on oath. In the only example we have of an oath in the authorial voice Sappho chooses instead to stress her lack of joy in life and her desire to die, presumably as a result of a love-sickness. ${ }^{55}$ This kind of sentiment can be effectively emphasized by an oath, which immediately implies that the statement is true and, in this case, weighty. Moreover the emphatic woe of the speaker stresses the desirability of the unattainable lover, so that this oath made in the authorial voice is comparable in function to those made to praise an honorand in epinician poetry. The statement is probably made

53 See W.J. Slater 1969 and Carey 1995b, 99-103.

54 Pfeijffer 1999, 23, notes that "the announcement is directly followed by its fulfillment" in this and other examples of first person futures in Pindar. For an oath offered (with a future tense) but not sworn, cf. h.Herm. 274-6 with §7.3.3.

55 Boedeker 1979 gives an illuminating analysis of the imagery exploited in Sappho fr. 95 and demonstrates that "Acheron is transformed to a world of love" which reinforces "the erotic nature of the death-wish" (49), suggesting further that "the desire to die is caused by unfulfilled love" (51). 
to Hermes, ${ }^{56}$ so that if the oath is indeed made in the poet's voice, ${ }^{57}$ the interaction with a divinity reveals a fictionalized rather than an actual self. ${ }^{58}$

The informal oath in the anonymous Theognidea is at the other end of the emotional spectrum. ${ }^{59}$ The authorial voice claims, "by Zeus" (voì $\mu \dot{\alpha} \Delta^{\prime}$ ') that even if one of those in the house is sleeping well wrapped up, the revel (kōmos) of the poet and his band will be eagerly welcomed (1045-6). In other words, even someone who is sound asleep will be delighted to welcome the revellers. One would imagine such a scenario to be highly unlikely, unless, of course, the poetry performed by the revellers is so irresistible that it could charm even someone woken from a deep sleep. The oath is linked to the poet's sense of the value of his own poetry here far more directly than in Pindar, where oaths (as we saw) are associated with excellent poetry by virtue of their association with the truth. Theognis is not shy about drawing attention to his poetic skill when, for example, he asks his friend Cyrnus to lock away his verses, suggesting that if they are stolen all will recognize them as his work since his name is famous everywhere (19-24). It seems that Theognis was keen to defend his worth after political upheavals in which he was disfranchised and exiled, ${ }^{60}$ and it is remarkable that all the references to oaths in the anonymous Theognidea relate to the dangers of oaths except for this one example in the authorial voice. So the listener is warned not to gain wealth by a false oath because the gods will prevail (197-202), and not to trust anyone in any sworn pledge of friendship, not even if he has invoked the king of the immortals Zeus as his guarantor (283-6). The good man should shun ruinous perjury and avoid the immortals' wrath (399-400). One should never swear that something will never be since the gods resent it and they control the outcome (659-60). How is it possible for a righteous man, the kind who does not commit perjury, to suffer unrighteously (745-6)? One should not raise up a tyrant nor make a sworn conspiracy to kill one (823-4). The judicial oaths of men can no longer be trusted (1139). If we take the corpus as a whole, a consistent view emerges of a poet who believes in the value of his own poetry and of his own oath

56 Boedeker 1979, 44-5 summarizes the arguments.

57 It is possible that the first-person speech was attributed to a particular character in a lost part of the poem; see Boedeker 1979, 43.

58 Cf. Stehle 1997, 300, and Burnett 1983, 294 who speaks of "Sappho (a fictional Sappho)".

59 In referring to Theognis versus the anonymous Theognidea, I follow the groupings of M.L. West 1993, although the relevant passages are discussed together and a speculative conclusion is reached regarding a coherent authorial attitude to oaths in these texts.

60 M.L. West 1993, xiv, and see Cobb-Stevens 1985 on the unsettled political world of Theognis; Figueira 1985, 155 notes that the theme of exile is prominent in the Theognidea, and Selle 2008, 158-65 gives a useful summary of themes within the corpus. 
but who has reason to distrust the oaths of others after (one presumes) having been betrayed. ${ }^{61}$

Our final examples of a poet swearing in the authorial voice are rather different in the sense that, whatever arguments are made concerning the poetic "I" in lyric poetry, the "voice of Aristophanes" is certainly conveyed by a chorus member rather than by the poet himself but the sentiments expressed relate directly to the real Aristophanes. Both oaths stress the poet's disappointment at the lack of appreciation for his first production of Clouds, which had been ranked third and last at the City Dionysia of $423 \mathrm{BC}$, but they represent two distinct modes of authorial communication. In Wasps, produced the next year, at the Lenaea of $422 \mathrm{BC}$, the chorus reports in their own fictional identity that Aristophanes swears vehemently "by Dionysus" that no one ever heard better comic poetry than his Clouds (Wasps 1045-6). ${ }^{62}$ In the revised Clouds, which (unfortunately) was never performed, the chorus-leader speaks as if in the person of Aristophanes (518-25). He swears a formal oath "by Dionysus who reared me" that he will tell them the truth, namely that he thought the Athenians were clever and that the original Clouds was his most intellectual comedy (but he was defeated undeservedly by vulgar men). Unusually, rewards are specified for giving a true oath but no punishments are named: may Aristophanes be victorious and may he be thought of as clever (Clouds 520). This is apparently the only known oath in our entire period in which there is a specification of blessings but none of curses; moreover, Aristophanes here mentions only rewards that are wholly within human control, whereas elsewhere, when blessings are specified at all, they are normally divine in nature. ${ }^{63}$ The oath is a way of soliciting votes from the judges and of promoting

61 M.L. West 1993, xiv, describes Theognis as "a man...who finds himself betrayed by those he trusted”. Another lyric poet who was betrayed by an alleged perjurer is Alcaeus. The author reports that he swore a pact with his comrades in Lesbos that they would never abandon any of their company, but either die at the hands of men who came against them or kill them and rescue the people from their woes (fr. 129.13-24). The poet's invective is launched against Pittacus (son of Hyrrhas) for "trampling on the oaths" of his fellow men in joining the tyrant Myrsilus and sharing power with him. The issue is also referred to in fr.306(g).9-11 and possibly in fr. 167.1. In fr.129 Alcaeus calls for an avenging curse to pursue Pittacus, but in fact, Pittacus would be chosen as dictator in 590 when Myrsilus died, and ruled till 580. The authorial voice here is rather different than in our other examples since the poet is not making a statement on oath within his own poetry but is rather using his poetry to discuss the breach of an oath he had sworn in a pact with others. Archilochus also casts a former friend (Lycambes) as a perjurer in fr. 173, on which see further $\S 5.3$.

62 Cf. $\$ 6.3$ on the sanctifying features of this oath.

63 An exception is the Hippocratic Oath, which (I argue) is unusual for this reason (see ch. 14). 
the quality of the drama. ${ }^{64}$ Moreover, if the oath is true, and we can reasonably assume that Aristophanes really did believe that his Clouds was under-appreciated, it cleverly implies that Aristophanes' play must win, and that he must be thought of as clever, and it is regrettable that the rhetoric was never used on any real judges.

The authorial voice presented by the chorus in Clouds undisputedly represents the identity of its creator Aristophanes who is bringing to the fore a deeply personal issue. In the Wasps passage, the author is referred to in the third person rather than in the first, and although this means that the poetic "I" is technically absent, it is not far away. ${ }^{65}$ Certainly the presence of Aristophanes' voice in his plays is more obvious than that of Xenophon in the Anabasis, who disguises his authorial voice in several ways as we shall now see. We can conclude here by observing that oaths in the authorial voice tend to be used in poetry for the purposes of praise, either of an honorand as in Bacchylides and Sappho, or of the poet's own skill as in the anonymous Theognidea and Aristophanes, or both as in Pindar.

\section{3a.3 Xenophon}

The case of first-person oaths in Xenophon is quite unique. He appears as a character in the Anabasis and briefly in the Memorabilia, and the former of these works will be the most important for our discussion. Although ostensibly a historical narrative of events in which the author played an active role, the Anabasis is carefully constructed with a substantial degree of literary artifice, which utilizes a unique narrative strategy. ${ }^{66}$ The "anonymous" or "pseudonymous" narrator describes the actions and speeches of Xenophon in the third person, or in reported first-person discourse, which provides a strong first-person presence in spite of the layers of mediation between Xenophon the author and actual historical figure and Xenophon the character. The issue is complicated further by the fact that Xenophon famously claimed in his Hellenica (3.1.2) that Themistogenes of Syracuse was the author of the Anabasis. Plutarch commented on this, observ-

\footnotetext{
64 On self-promotion in the dramas of Aristophanes, see M.E. Wright 2012, 71-7, who argues for an ironical reading of the relevant passages.

65 Compare the parabases of Acharnians and Peace where the poet starts by being third person and then, without warning, shifts into first (at Ach. 660 and Peace 754).

66 See Bradley 2010 for full discussion of the Anabasis as a unique manipulation of genre and narrative.
} 
ing that Xenophon was more persuasive in writing about himself as if about another (Moralia 345e). ${ }^{67}$

In other authors, first-person oaths stress the presence, opinion, or experience of the author as speaker and can represent an intrusion of the authorial voice into an otherwise fictional or mythological context (as in Aristophanes or in Pindar). In Xenophon's Anabasis, by contrast, the artificial degree of separation between "author" and "persona" is such that oaths placed in the mouth of Xenophon the character appear impartial and objective, in spite of the fact that Xenophon the author has a vested interest in presenting Xenophon the character in as positive a light as possible. Xenophon the character is successfully presented as a moderate and pious man, a good (if reluctant) leader who cares about the welfare of his troops. The oaths he swears help to create this persona and by swearing oaths that are shown to be true, his piety is confirmed. Moreover the statements made on oath, which mostly concern his care for his troops and his defence against a variety of charges, demonstrate in an apparently disinterested fashion that Xenophon is an exemplary leader.

The first such oath in the Anabasis comes in the report of an outrage committed by some Greeks in Cerasus who start a riot of stoning in which three ambassadors are killed. The rioters then arrive at the camp of the Ten Thousand while the Cerasuntians are holding discussions with the generals concerning the burial of some soldiers recently killed. The Cerasuntians flee back to their ships in terror (Anab. 5.7.19-22), and "by Zeus", says the character Xenophon, "some of our own were afraid” (5.7.22). The point is carefully made. The troops are not as fearful as the Cerasuntians who flee, and clearly Xenophon was not afraid since he goes up to the men to ask what the trouble was (5.7.23). In fact, he uses the episode as a platform from which to expose the negative impact of impious and lawless behaviour (5.7.23-33). Upon his recommendation it was then resolved to purify the army (5.7.35). The seemingly conversational oath by Zeus thus serves to emphasize the bravery and wisdom displayed by Xenophon as a leader, in contrast to the troops who were afraid or behaving impiously.

The character Xenophon also uses oaths to defend himself against charges of inappropriate behaviour. When accused of beating his men unfairly, for example, he had replied "by Zeus" that since his accusers had taken no stand, neither coming to the aid of the men being beaten nor joining in the beating, they must have deemed the action to have been justified (Anab. 5.8.21). Imme-

67 For a discussion of Xenophon's reasons for writing the Anabasis, see Cawkwell 2004, esp. 59-67. Grethlein 2012 discusses how the narrator often takes on the perspective of Xenophon the character thus contributing further to his positive and apparently impartial representation. 
diately preceding the oath, the accusation had been lightened by a humorous self-depreciation, ${ }^{68}$ where Xenophon claims that he now drinks more wine than he did before but is hitting no one since he sees that the men are in "fair weather" (5.8.19-20), i.e. that there is no emergency justifying drastic action. Since drinking makes physical violence more likely, Xenophon cleverly demonstrates that he is self-controlled by nature. The statement on oath then presents his action not only as entirely justified, but also as the decisive measure taken by a natural leader in the face of indecision.

The majority of oaths sworn by Xenophon's character, however, cluster around the accusation that he gained wealth at the expense of his men. In a series of oaths, Xenophon stresses not only that he has made no material gain, but also that the welfare of his troops is his foremost concern. The issue arises after Xenophon had persuaded the men to serve as mercenaries in the army of the Thracian prince Seuthes during the winter of 399, but the men fail to receive their agreed wages. Xenophon is presented as defending the interests of his army when Seuthes' retainer Heracleides claims that there was only money available to pay the men for twenty days of the previous month. Xenophon becomes enraged and "replied with an oath" (eipen epomosas) that Heracleides was not caring for the interests of Seuthes. If he had been, he would have paid the Greeks in full, even if it meant borrowing money or selling his own clothes (Anab. 7.5.5). The insignificant Heracleides is blamed so that a direct confrontation with Seuthes is deftly avoided. Heracleides is infuriated by Xenophon's insults and proceeds to slander him before Seuthes "to the best of his ability" (7.5.6). As events develop, Xenophon's leadership is challenged further when the Spartans come to recruit the remainder of the Ten Thousand and Heracleides and Seuthes, seeing their chance to end the service of the Greeks without settling their payment, invite the Spartans to solicit the troops predicting that they will quickly abandon Xenophon. An unnamed soldier accuses Xenophon of having profited at the expense of the troops and he is followed by another and another (7.6.9-10). The scene is set for Xenophon to give his defence speech.

Xenophon swears "by Zeus" that he had turned back after he had set out for home because he had heard the men were suffering and so he returned to help in any way he could (7.6.11). He then swears a formal oath "by all the gods and goddesses" that he has not even received what Seuthes promised to him for his own services and that since Seuthes is present, he knows well whether or not Xenophon is swearing falsely (7.6.18); and he swears in addition (sunepomnumi) that he has not even received as much as the other generals or even as some of

68 Flower 2012, 105 discusses this technique. 
the captains (7.6.19). Xenophon's use of oath-language here is reminiscent of the pattern we saw in Aeschines and Demosthenes (see p. 349) where more serious oaths involve the invocation of more elaborate oath-witnesses than the common informal oath formula “by Zeus”. This weaker formula is used in Xenophon's next oath when he anticipates, precisely in the manner of the imaginary objector (eipoi ... tis an), that he will be asked whether he is ashamed of being so stupidly deceived by Seuthes. He swears "by Zeus" that he would have been ashamed to be deceived by an enemy, but that in dealings between friends it is deceiving (not being deceived) that is shameful (7.6.21).

Xenophon's main claim, that the welfare of his men is his prime concern, is immediately validated after he has finished his speech by the Spartan Charminus who swears an oath relating a mildly exaggerated version of Seuthes' criticism of Xenophon as a man who is a friend to the soldiers (made at Anab. 7.6.4), now repeated as being "too much a friend to the soldiers" (7.6.39). The oath, which is an ethnically appropriate invocation of "the twin gods" ( $t \bar{o}$ siō), ${ }^{69}$ smacks of impartial authenticity, and as Flower comments, "the fact that Seuthes makes this remark and that the Spartans believe it is proof for the audience that Xenophon was not in fact receiving money from Seuthes and did not deceive his fellow Greeks."70 Xenophon twice more swears formal oaths protesting his innocence in relation to these accusations, both in a private meeting with Seuthes. He calls the gods to witness that he had neither received anything from Seuthes that was intended for the soldiers, nor asked for his private use anything that belonged to them, nor demanded from Seuthes what he had promised (7.7.39). Of course, as Flower observes, he never claims that he did not receive payment for his position as general; ${ }^{71}$ and in the final oath protesting his innocence, Xenophon swears (omnumi) that even if Seuthes had offered to pay what was due to him, he would not have accepted it unless the soldiers were also to recover what was due to them (7.7.40). The veracity of such a statement can be neither confirmed nor refuted since it is an oath (and a formal one) about what Xenophon would have done in a hypothetical situation that never actually existed. It is thus a particularly pure case of a statement for which the oath provides the sole possible means of confirmation. Whether or not the audience believes the statement depends to a large degree on whether or not Xenophon is the kind of person who would use

69 The oath "by the twin gods" (i.e. Castor and Polydeuces) was specifically a Spartan oath; see further \$13.1. On occasional references to the different religious customs of the different ethnic groups among the Ten Thousand, see Parker 2004, 139-40.

70 Flower 2012, 164.

71 Flower 2012, 158. 
oaths impiously, and Xenophon the author works very hard to make us believe that Xenophon the character would not have done so. ${ }^{72}$ Therefore the audience is guided implicitly to believe Xenophon's sworn statements.

Xenophon's actions in the Anabasis are consistently validated by acts of divination, ${ }^{73}$ and two further passages contain oaths sworn by Xenophon presented in conjunction with sacrificial divination. In a passage relating to the sale of his horse, Xenophon is reported to have stated on oath (epomosas eipen) to the seer Eucleides that he would not have enough money to pay his travelling expenses on the way home unless he sold his horse and his personal belongings (Anab. 7.8.2). Eucleides did not believe him, but subsequently realized that Xenophon was telling the truth when he saw the sacrificial offerings (7.8.3). This is, chronologically, the last oath sworn by the character Xenophon in the Anabasis, and it is a rhetorical tour de force. The passage is important for addressing the potential for audience incredulity regarding Xenophon's alleged poverty. ${ }^{74}$ However the audience is also presented with an objector (actual rather than imaginary) to Xenophon's oaths and with one who is a religious expert. The seer then uses his skill at divination to determine that Xenophon's oath was truthful! The narrator is conveniently silent on what sign from the sacrifice would have confirmed this, ${ }^{75}$ but if the audience ever had reason to suspect any of Xenophon's previous oaths, even minor doubts can now be firmly dispelled.

Sacrificial signs are decisive and authoritative factors throughout the narrative of the Anabasis. In particular, signs from the gods are presented as corroborating Xenophon's decision to decline the command of the Ten Thousand in the first instance. Sacrificial offerings, the oracle of Apollo, a dream and bird omens are all mentioned (Anab. 6.1.22-24), and he further confirms with a formal oath, swearing by all the gods and goddesses, that when he became aware of the army's intention to elect him as sole leader, he offered sacrifices and the gods revealed clearly that he must not accept the command (6.1.31). The decision proved fortuitous since Cheirisophus, who did accept the leadership, only managed to hold on to it for a few days due to the dissatisfaction of the army. It is beyond the scope of the present study to delve deeper into Xenophon's broader use of oaths in his writings, but already we have noticed some distinctive trends. We saw in $§ 6.3$ that

72 Cf. Flower 2012, 159. Dillery 1995, 182-6 discusses Xenophon's religious views, and comments on "Xenophon's profound commitment to the sanctity of the oath" (184).

73 On this issue see e.g. Parker 2004, who comments at 133: "For Xenophon, one might say, Greek religion is above all a religion of divination”; cf. also Flower 2012, 33-4.

74 See Flower 2012, 213.

75 Cf. Parker 2004, 145 who points to "our ignorance of exactly how 'good' and 'bad' omens were determined". 
Xenophon mentions the handclasp as a sanctifying gesture in various oaths as a means of stressing both friendship and betrayal. Here we see that Xenophon, the third-person character in the Anabasis, is made to swear a cluster of oaths, most of which are formal, and all of which pertain to his self-presentation as a pious leader whose primary concern is for the welfare of his army.

Xenophon's writings contain just three further oaths sworn in the various manifestations of the authorial persona, all of which are informal. The character Xenophon swears one in the Memorabilia, and two more are sworn by the narrator, one in the Hellenica and one in the Constitution of the Spartans. Each of these oaths conforms to patterns of authorial swearing that we have already noticed in the Anabasis. They are used to create the illusion of impartiality in representing the character Xenophon (Mem.), or to stress that wealth is undesirable. In the Memorabilia, as in the Anabasis, although in a far more minor role, the character Xenophon is introduced in the third person "in order to secure an impression of objectivity and hence persuasive force". ${ }^{76}$ This sense of objectivity is increased by the fact that Socrates shows Xenophon to be foolish (Mem. 1.3.8-13), and it is in this exchange that the oath occurs. Xenophon is surprised to discover the apparent dangers of a mere kiss to a pretty face. Socrates then asks Xenophon to confirm that venomous spiders although small creatures can inflict excruciating and maddening pain if they fasten on the mouth. "Yes by Zeus" (voì $\mu \dot{\alpha} \Delta$ '́) confirms Xenophon, because they inject something with their bite (1.3.12). Socrates is now free to deliver his concluding point, namely that a pretty face is more dangerous than a venomous spider since it can inject a maddening poison from afar (1.3.13). The oath here serves to heighten the image of Xenophon as a disciple of Socrates, learning from Socrates' wisdom.

Our final two authorial oaths in Xenophon are statements made by the narrator. In the Hellenica, the narrative "I" intrudes to stress "by Zeus" (voì $\mu \alpha \dot{\alpha} \Delta$ í $\alpha$ ) that it seems well worth while to consider what Teleutias did to inspire his men to be well disposed to him, adding that this is a more noteworthy accomplishment for a man than amassing money or facing many dangers (Hell. 5.1.4). We will later discover that it was his devotion to their welfare and his willingness to share their hardships that gained their favour (5.1.14-15). It is remarkable that this single oath in the authorial voice from the Hellenica, our only oath in the authorial voice from all surviving fifth- and fourth-century historiography, should echo precisely the qualities stressed on oath by Xenophon's character in the Anabasis regarding his own leadership qualities. Given the fact that we are told in the Hellenica that the Anabasis was written by someone other than Xenophon, it seems that Xeno-

76 Gray 2004, 377, and for more detail see Gray 1998, 94-104. 
phon may have exploited the first-person oath with his direct authorial voice in the Hellenica to stress the leadership qualities of Xenophon the character in the Anabasis, albeit implicitly, by virtue of the fact that they are entirely comparable to those of Teleutias. Certainly it is uncanny that the statement made on oath in the first person is so similar in its concerns to the first-person oaths made by Xenophon the character in the Anabasis.

The authorial oath from the Constitution of the Spartans also expresses a related concern, confirming the negative power of wealth in a more general way. Towards the end of the treatise, the narrative "I" states emphatically: "should anyone ask me whether I believe that the laws of Lycurgus remain unchanged to this day, this by Zeus ( $\mu \alpha \dot{\alpha} \Delta$ í ) I could not say with any confidence" (Lac.Pol. 14.1). The statement is provocative since any contemporary Spartan, asked the same question, would presumably have responded “of course!”, and Xenophon's carefully crafted exploitation of the first-person oath elsewhere in his writings suggests that this oath too is purposely inserted for rhetorical effect. We are subsequently told that Spartans used to prefer living moderately rather than being corrupted by flatterers in other cities (Lac.Pol. 14.2), and that they were formerly afraid to appear to be in possession of gold whereas now some even boast of it (Lac.Pol. 14.3). In what is ostensibly a work praising Sparta, the criticism is unexpected and it has been explained, by some, as representing Xenophon's disappointment with his contemporary Spartans. ${ }^{77}$ Others, however, have stressed that a tension between praise and veiled criticism is present throughout Xenophon's writings on Sparta, ${ }^{78}$ and Noreen Humble has argued that certain flaws in the Spartan system are implied through the first thirteen chapters of the Constitution of the Spartans so that "Chapter 14...provides an insightful summary" of those flaws. ${ }^{79}$ Humble suggests that Xenophon saw how, through the Lycurgan system, Sparta came to power and then fell, and that it was "this paradoxical quality of the Spartan system" with which Xenophon was concerned in this particular work. ${ }^{80}$ The oath in the authorial voice supports this interpretation since it too is paradoxical in its expression. Its language implies that the laws of Lycurgus may no longer be in place (or that contemporary Spartans are no longer adhering to them), but the statement is formulated around whether or not Xenophon

77 For example, Lipka 2002, 33-4 suggests that "Chapter 14 [of the Constitution of the Spartans] ...deserves a high degree of credibility, if only due to its unexpected criticism of Spartan affairs". See Humble 2004, 215 with nn. 2 and 3 for further references.

78 See Strauss 1939, Higgins 1977, 65-75, Proietti 1987.

79 Humble 2004, 225.

80 Humble 2004, 227. 
believes this to be the case, and he does not actually commit to an opinion. In other words, he does not censure the Spartans, but by raising the question at all and by marking it with an oath in the authorial persona, he paradoxically implies a deterioration in the Spartan system which he claims to be unable to determine.

\section{3a.4 Three more authorial oaths in prose texts}

Outside Xenophon, Aeschines and Demosthenes, we rarely find first-person oaths in prose authors of the classical period. In one fragment of Antisthenes (fr. 187.4-5 Giannantoni), the author apparently swears "by Zeus" ( $\mu \dot{\alpha} \Delta \Delta^{\prime} \alpha$ ) that Homer did not make the character of wise Nestor treacherous and duplicitous. The statement is made during a discussion of portrayal of character in Homer where Antisthenes is concerned with defending the reputation of Odysseus, who, he says, is more blamed than praised by the poet in comparison to other characters. We cannot say for certain that the oath belonged to Antisthenes' original text since the passage is reported by Porphyry in a scholium on Odyssey 1.1. However, the expression would be at home in the genre, and we cannot rule out the possibility that Porphyry's report is quoted carefully. The oath here signifies that no one could doubt the integrity of Nestor's character, creating a contrast between Nestor and the other characters mentioned (Agamemnon, Ajax and Achilles). The oath suggests that Nestor is even more noble than the others, so that an oath in the authorial person is here used once again for the purpose of praise. ${ }^{81}$

It is, by contrast, the lack of nobility which is emphasized in the authorial oath from Letter VII attributed to Plato. In the letter, written ostensibly by Plato to the friends and family of the dead Dion, the author swears "by the gods" (vin

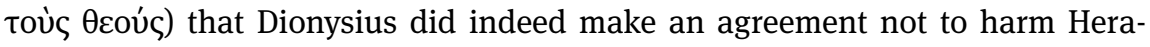
cleides (349b4-7). The exchange reported takes place during Plato's third Sicilian visit. Dionysius has just angrily denied making any such agreement with Plato, "looking at [him] in a very tyrannical fashion". It is technically true that he did not make the agreement "with Plato" since he made the promise to Theodotes the previous day in Plato's presence (348d-349b), but the use of an oath here emphasizes what is important, namely that the agreement had been made. The tyrant's failure to keep his agreements is thus stressed.

Our final example comes from the works of Aristotle, which contain just one oath in the authorial voice. This occurs in Politics (1281b18) where we are told, "by

81 On the treatise in which this passage occurs, and on Antisthenes' defence of Odysseus more generally, see Montiglio 2011, 20-37. 
Zeus" (nē Dia) that perhaps it is clear that in certain collectivities it cannot possibly be true that the many have more intelligence than the few. The concept being discussed here is that the many have more intelligence than the few because there are more of them, and a collective judgment will be better than the judgment of a few regardless of intelligence. But this may not always be true, and in some cases it most certainly is not. For example, many animals will not have more intelligence than a few men - and, Aristotle adds, there are some humans who for all intents and purposes are no better than animals. However, he immediately goes on to say that a blanket rejection of the "wisdom of crowds" principle would be equally unjustified (1281b18-21). The oath "by Zeus" is the weakest form of informal oath (see \$13.2) and here it emphasizes a conjecture qualified by "perhaps" (isōs), but the passage is noteworthy all the same. Aristotle swears here in his own name for the only time in his entire corpus, and he does so to emphasize a claim that (in effect) democracy is not always the best form of government, and adds, irrelevantly (and contrary to his own theories of the soul and of mental faculties), that "some people" are "no different from animals." The conversational form of this type of informal oath is perhaps an indication that Aristotle has let his guard down momentarily: he asserts on oath a statement which he believes to be true, even though he subsequently tries to cover his tracks.

\section{3a.5 Conclusions}

Although oaths in the authorial persona appear in a diverse range of genres, each of which has its own idiosyncrasies and agendas, we can nevertheless discern a general pattern in which authors consistently introduce oaths in the authorial persona to stress that something is especially worthy of belief. We have seen that Xenophon's use of oaths in the authorial person, the vast majority of which occur in the Anabasis, is unique, since it appears to present an impartial record of events in which Xenophon the character is distanced from Xenophon the author. It is significant, however, that of the remaining authors who most often use firstperson oaths in their works, two pairs of rivals emerge: Aeschines and Demosthenes, and Pindar and Bacchylides. The two authorial oaths of Aristophanes are also delivered in a context of rivalry. It seems possible, then, that certain authors include first person oaths in their own works as part of a framework of rivalry. We have already noted that among the orators oaths in the authorial voice only occur in the speeches of the political rivals Aeschines and Demosthenes, and we also saw how one of Bacchylides' two surviving first-person oaths (5.41) occurs in an ode written to commemorate an event which Pindar's first Olympian also 
celebrates. Use of first-person oaths may have developed in these authors, in part at least, through their responses to each other. ${ }^{82}$

Another distinctive thread in our discussion has been exploitation of the first-person oath by poets to stress the value of their own work, as occurs most obviously in Pindar, the anonymous Theognidea, and Aristophanes, or to elevate praise of an honorand (as in Pindar, Bacchylides, and possibly Sappho). Nevertheless, we are left to account for the absence of the authorial oath in some of the major authors of the archaic and classical periods. This can be explained by looking at the narrative techniques of the relevant authors. In Homeric epic the poetic "I" is virtually absent, ${ }^{83}$ and the narrator's voice, which plays an important role in the Odyssey, especially, exists there in a complex relationship with Odysseus' own narrative voice. ${ }^{84}$ Mark Griffith has demonstrated that "according to the conventions of heroic and hymnic poetry, we should not expect [the poet] to intrude himself or his personal opinions there." 85 This analysis holds for the Homeric epics, for the Homeric Hymns which are not strongly tied to a specific location or occasion, ${ }^{86}$ and for Hesiod's Theogony. ${ }^{87}$ As for the absence of first-person oaths in Hesiod's Works and Days, where the poet frequently speaks in an authorial voice, I would suggest that this can be explained by considering the content of the poem. Authorial oaths in poetry are intrinsically linked with praise, either of the honorand or of the poet, but Hesiod's Works and Days is not concerned with praise. Rather, Hesiod famously claims that he will tell etētuma "things as they are" (10). ${ }^{88}$ The type of poem, didactic rather than honorific, helps to explain the lack of authorial oaths, as does the representation of oaths in the Works and Days. In the Theogony the binding nature of oaths and punishment for their breach is stressed, both for mortals and for gods (231-2, 400, 784, 793-806). In Works and Days, however, the first mention of oaths comes in a prediction for

82 In a different context, oaths could also be used to cap a rival's claims in comedy where the capping of one oath by another might be exploited as a clever rhetorical technique. See Sommerstein 2007b, 127-8 and §13.2, p. 335.

83 The opening invocation of the Muse in the Odyssey contains the personal pronoun ( $\mu$ o "to me") but the equivalent invocation in the Iliad does not.

84 See Goldhill 1991, 1-68, Segal 1994, 113-86.

85 Griffith 1983, 50.

86 See Griffith 1983, 44-6.

87 For a defence of this view of Hesiod's Theogony, see Griffith 1983, 50-5.

88 Clay 2003, 78 stresses this aspect of Works and Days in contrast to the Theogony whose purpose is to praise the gods. Stoddard 2004, 191, makes the radical suggestion that "Hesiod adopts the role of the unreliable narrator" in Works and Days (emphasis original). It is unclear why an author would wish to present his own voice as unreliable, but Stoddard states that she will discuss the issue fully in a forthcoming book. 
a time in the near future when the righteous man who abides by his oath will receive no reward, while the villain will actively swear false oaths for his own gain (190-4). This lack of regard for the man who keeps his oath resembles the conduct of the poem's addressee Perses, and subsequent references to forsworn oaths being punished $(219,282-5,803-4)$ are also warnings to Perses. ${ }^{89}$ This negative emphasis on the dangers of oaths and oath-taking, in addition to the didactic nature of the poem, which does not seem to lend itself to first-person oath statements, explains why the authorial oath is absent.

We are left with the absence of authorial oaths in Herodotus and Thucydides. As with Hesiod, this can be explained, in part at least, by looking at each author's attitude to oaths. It is well known that many aspects of traditional religion do not feature strongly in Thucydides, although religion is not entirely absent from his narrative. ${ }^{90}$ Oaths do feature regularly in his writing but, as Lateiner has shown, his interest in oaths is very much focused on sworn inter-state agreements, their breach, and how "[o]aths and their violations delicately indicate the decline of traditional social and religious practices, as well as of traditional politics."91 Since Thucydides' attitude to oaths implies that they are not to be trusted, it makes sense that he avoids making any sworn statements in the authorial voice. At first glance, it is more surprising that Herodotus does not use the technique, but this too can be explained by looking at Herodotus' broader narrative strategies and his attitudes to oaths. Herodotus is prone to giving his audience alternative explanations for various events, phenomena, and cultural customs. ${ }^{92}$ Sometimes he voices a preference for one explanation over another, but he tends not to try to present his opinion as fact. ${ }^{93}$ Moreover the authorial voice in Herodotus, which is both the voice of the narrator and the voice which focalizes the reports of others, emerges as an early form of the distanced "expert persona" due to the fact that Herodotus eschews relating autobiographical information. ${ }^{94}$ This type of authorial voice does not lend itself particularly well to first-person oath-statements, which, as we have seen, are often used to suggest the factual nature of an utterance and represent an especially marked intrusion of the authorial persona

89 See Clay 2003, 38-43.

90 See e.g. Hornblower 2011, 25-53.

91 Lateiner 2012, 170.

92 This is particularly the case with events or issues that are remote in relation to his contemporary Greece. See Hornblower 2002 for an overview of scholarship and further discussion on how Herodotus presents his sources.

93 Dewald 2002, 279 notes that Herodotus' critical comments tend to be speculative opinions rather than expressions of certainty.

94 See Dewald 2002, which supersedes Dewald 1987. 
into the narrative. It is telling that there is not a single instance of an informal oath in Herodotus' Histories, which is the type of conversational oath most commonly used for swearing statements in the authorial person, and the absence of informal oaths confirms Lateiner's analysis of Herodotus' attitude to oaths: "Herodotus observed the potency of traditional oaths in familiar and alien societies, but he perceived that many oath-takers forswear their oaths or find dubious ways to claim that they had honoured them". ${ }^{95}$ Oaths in Herodotus are serious, binding, and dangerous. In this light it is not surprising that he too avoids committing his authorial voice to sworn statements.

95 Lateiner 2012, 169. Cf. T. Harrison 2000, 120 who observes that Herodotus' Histories "provide ample evidence of the expectation of perjury.” 